\title{
Economic viability of 'Niágara Rosada' grape production in the north and northwest regions of Rio de Janeiro
}

\author{
Jaomara Nascimento da Silva ${ }^{1}$, Niraldo José Ponciano ${ }^{2}$, Claudio Luiz Melo Souza ${ }^{3}$, \\ Paulo Marcelo de Souza ${ }^{4}$, Leandro Hespanhol Viana ${ }^{5}$, Marcelo Geraldo de Morais Silva ${ }^{6}$
}

\begin{abstract}
The 'Niágara Rosada' grape (Vitis labrusca) is the main table cultivar produced in the North and Northwest Regions of the Rio de Janeiro State. This cultivar presents greater rusticity and lower production cost than the cultivars of fine grape (Vitis vinifera L.) because it is more resistant to diseases and the absence of some cultural treatments. The research aimed to determine the economic affordability of the production of 'Niágara Rosada' grapes in the north and northwest regions of Rio de Janeiro state, by calculating the Net Present Value (NPV) and the Internal Rate of Return (IRR), and to identify the risk of viticulture, through the sensitivity analysis and the use of the Monte Carlo method. To collect the data, questionnaires, and interviews were applied directly to the wine producers on the technical coefficients and respective production costs of the grape in 1 ha. The results highlighted that viticulture could be a good alternative for the regions, with satisfactory profitability. The variables with the most significant effect on profitability were the sale price of the product, the cost of labor, and the price of packaging. The probability of winegrowers to obtain a negative NPV is $33.32 \%$, considering an attractiveness rate of $6 \%$ per year. Index terms: production costs, tropical fruit growing, Monte Carlo Simulation, viticulture.
\end{abstract}

\section{Viabilidade econômica da produção de uva 'Niágara Rosada' nas regiões norte e noroeste fluminense do Rio de Janeiro}

Corresponding author: jaomarasilva@gmail.com

Received: June 23, 2020 Accepted: September 17, 2020

Copyright: All the contents of this journal, except where otherwise noted, is licensed under a Creative Commons Attribution License.

\section{(cc) $\mathrm{EY}$}

\begin{abstract}
Resumo - A uva 'Niágara Rosada' (Vitis labrusca) é a principal cultivar de mesa produzida nas regiões norte e noroeste do Estado do Rio de Janeiro. Esta cultivar apresenta maior rusticidade e menor custo de produção em relação às cultivares de uva fina (Vitis vinifera L.), por ser mais resistente às doenças e pela ausência de alguns tratos culturais. A pesquisa teve como objetivo determinar a viabilidade econômica da produção da uva 'Niágara Rosada' nas regiões norte e noroeste fluminense, por meio do cálculo do Valor Presente Líquido (VPL) e da Taxa Interna de Retorno (TIR), e identificar o risco da viticultura, mediante a análise de sensibilidade e o uso do método de Monte Carlo. Para o levantamento dos dados foram aplicados questionários e entrevistas diretamente aos viticultores sobre os coeficientes técnicos e respectivos custos de produção da uva em 1 ha. Os resultados mostraram que a viticultura pode ser uma boa alternativa para as regiões, com rentabilidade satisfatória. As variáveis com maior efeito sobre a rentabilidade foram: o preço de venda do produto, o custo da mão de obra, e o preço das embalagens. A probabilidade de os viticultores obterem um VPL negativo é de $33,32 \%$, considerando-se a taxa de atratividade de $6 \%$ ao ano.
\end{abstract}

Termos para indexação: custos de produção, fruticultura tropical, Simulação Monte Carlo, viticultura.

\footnotetext{
${ }^{1} \mathrm{PhD}$ Student in Plant Production of State University of Fluminense North, Campos dos Goytacazes-RJ. Brazil. E-mail: jaomarasilva@gmail. com (ORCID 0000-0002-7002-1427)

${ }^{2} \mathrm{PhD}$ in Applied Economics, Professor, Estadual University of Fluminense North, Campos dos Goytacazes-RJ. Brazil. E-mail: njponciano@, gmail.com (ORCID 0000-0002-8663-5458)

${ }^{3} \mathrm{PhD}$ in Plant Production, Professor, State University of Fluminense North, Campos dos Goytacazes-RJ. Brazil. E-mail: claudiomelo.edu@ gmail.com ${ }^{\text {(ORCID 0000-0002-0506-4121) }}$

${ }^{4} \mathrm{PhD}$ in Applied Economics, Professor, Estadual University of Fluminense North, Campos dos Goytacazes-RJ. Brazil. E-mail: pmsouza@ uenf.br (ORCID 0000-0002-5788-915X)

${ }^{5} \mathrm{PhD}$ in Plant Production of State University of Fluminense North, Campos dos Goytacazes-RJ. Brazil. E-mail: lehespanhol@yahoo.com (ORCID 0000-0003-4187-1710)

${ }^{6} \mathrm{PhD}$ in Plant Production of State University of Fluminense North, Professor Associado, Instituto Federal Fluminense, Cambuci - RJ, Brazil. E-mail: mcoro2003@yahoo.com.br ${ }^{\text {(ORCID 0000-0003-3365-0029) }}$
} 


\section{Introduction}

Grape production in the North and Northwest Fluminense Regions began in the 2000s. The evolution of this activity is due to the development of experimental research at the Universidade Estadual do Norte Fluminense, in parallel to the investment commercial production by a producer in the municipality of Cardoso Moreira and, subsequently, the performance of the "Frutificar" Program which encouraged other producers to undertake this production in other municipalities (PERMANHANI et al., 2014). In this way, viticulture became attractive as a source of agricultural diversification for producers who, in general, already worked with other agricultural productions, contributing to the development of the regions. (POMMER et al., 2009).

According to these authors, under the aspect of edaphoclimatic conditions, the excellent performance of vines in the regions is associated with the average rainfall index, the abundant water for irrigation, high temperatures, and high solar radiation. In addition to these aspects, the development of new varieties adapted to these climates and techniques specific to each condition allowed the cultivation of the vine in tropical conditions with harvest in more than one season during the year, as in the given regions and several other areas of the country, as stated by Tecchio et al. (2020).

Farmers have produced grapes with, without seeds, for fresh consumption or processing of juices and wines in the regions. Among these, the cultivar 'Niágara Rosada' is the dominant one, and also the one with the longest cultivation time in these regions. This cultivar is the main table grape planted in Brazil; it is an American table grape, with pits, much appreciated for fresh consumption, and excellent acceptance in the market. (MARTINS et al., 2014;).

The cultivar 'Niágara Rosada' has greater rusticity in the field than fine grape cultivars. It also has a higher resistance to fungal diseases, requires lower labor and input costs. In addition to the management factors, it has good acceptance in the domestic market, and the possibility of obtaining high prices when harvested in low supply (TECCHIO et al., 2011).

According to Hespanhol-Viana (2009), this cultivar has a phenological cycle and thermal condition close to those found in the Northwest of São Paulo. However, knowledge about production costs and the economic viability of this cultivar in the regions is scarce. It is essential to highlight that in addition to the importance of knowing the phenological phases and the behavior of the grapevine in the regions, it is essential that the cultivation present good technical and economic management since profitability is an indicator for the continuity and development of viticulture in any region.
Studies on the technical production coefficients can define actions that optimize the development of viticulture more competitively, and can also guide and subsidize the decision making of new producers. Among some studies performed on the economic viability of the grape in Brazil, highlight the following: the region of Jales (SP) by Cappelo et al. (2017), the São Francisco Valley region (PE) by Reis and Reis (2016), and Oeste Catarinense (RS) by Kreuz et al. (2005).

Few studies have considered the requirements particularities of the cultivars in the different regions, mostly analyzing the probability of economic production risk. This study aimed to analyze the economic viability of the production of 'Niágara Rosada' grapes and to evaluate, through sensitivity and risk analyses, the decision-making process of whether to undertake this activity or not.

\section{Materials and Methods}

\section{Source of information}

The analyzed properties were chosen based on recommendations from technicians, producers, and public bodies, such as EMATER and the Secretariat of Agriculture. A non-probabilistic sample was used in this research, as the population analyzed was very small, considering the data of all winegrowers (16) present in the north and northwest regions of Rio de Janeiro.

Data were collected from May 2017 to July 2019 by applying questionnaires with questions related to the quantity and price of inputs and products. The producers were monitored monthly to obtain information such as the adopted production system; the routine of grape production and marketing activities, duration of cultural treatments and daily value of activities, the origin of seedlings, plant spacing and age, acquisition of fertilizers and pesticides, cost of the irrigation system, and product packaging material. The lifespan of the crop has been estimated at 20 years.

The production cost coefficients of 1 hectare were considered, equivalent to the size of the grape cultivation found in $88 \%$ of the analyzed properties. The production systems are of the trellis type, with protection screens, and under drip irrigation. The planting density was 2,000 plants/ha (spacing of $2.50 \mathrm{~m} \times 2.00 \mathrm{~m}$ ) and the expected productivity was equal to 07 tons/ha in the $2^{\text {nd }}$ year, 15 tons/ha in the $3^{\text {rd }}$ year, and 25 in the $4^{\text {th }}$ year until the twentieth year. Productivity was defined, considering the 20 -years useful life of the crop, and the price of the product equivalent to $\mathrm{R} \$ 5.00 / \mathrm{kg}$.

\section{Economic Viability Assessment}

The survey of the technical coefficients of grape production in the regions provided the data to assess the expenses (fixed and variable) and revenues related to 
cultivation. After characterizing cash flows, the following economic indicators analyzed the viability of production: Net Present Value (NPV) and Internal Rate of Return (IRR), which can consider the effect of the dimension time over the monetary values.

NPV is the measure of wealth that the investment generates for the winegrower. It is a consistent tool to measure the purchasing power of an endowment of money over time. Thus, the NPV of an investment project can be defined as the algebraic sum of the discounted values of the cash flow associated with it. The following equation represents the calculation:

$$
N P V=-I+\sum_{t=1}^{n} \frac{C F_{t}}{(1+K)^{t}}
$$

I is the capital investment on the zero date; $\mathrm{CFt}$ represents the return on cash flow at date $t ; n$ is the deadline for project analysis (20 years), and $\mathrm{k}$ is the minimum rate required to perform the investment or capital cost for the project investment. The minimum rate of attractiveness (MRA) considered for this research is equivalent to $6 \%$ per year. This value represents the average rate of financing that producers can obtain in the regions.

The higher the NPV, the more attractive the production system will be. When the NPV is negative, it means that the investment will be economically unfeasible. Thus, the economic viability of the project analyzed by the NPV method is indicated by the positive difference between revenues and costs, updated according to a specific discount rate.

The Internal Rate of Return (IRR) indicates the rate that nullifies the NPV of the cash flow of investment in viticulture. It is the rate that makes the present value of future profits equivalent to those of expenses incurred, thus characterizing the rate of return on invested capital. The following expression describes the IRR:

$$
0=-I+\sum_{t=1}^{n} \frac{C F_{t}}{(1+I R R)^{t}}
$$

This indicator serves to decide to invest or not, since if the obtained IRR is higher than (MRA), the project is economically viable.

\section{Monte Carlo simulation}

In addition to productivity, input prices are likely to vary and affect cash flow. It is difficult to predict the future price levels or estimate the opportunity costs of a given input. Thus, to estimate the variation of these prices, the sensitivity analysis method was used. This analysis allows measuring the change in a result (or indicator) by changing each variable, both in relative and absolute terms. (PAREJA, 2009).
For Buarque (1991), the sensitivity analysis consists of measuring how much a pre-fixed change in one or more factors of the project can change the result. Therefore, it is possible to assess how changes in each variable (technical coefficients) can influence the profitability of cash flows from 'Niágara Rosada' grape production in the regions.

The analysis chose the indicator to be sensitized. The indicator's expression was determined as to the chosen parameters and variables by the Microsoft Excel ${ }^{\mathbb{B}}$ Program. From the introduction of the parameters' values in the expression, the simulation varied one or more parameters, checking how these variables affected the results, in terms of probability.

A numerical expression of variation of 5\% and 10\% were adopted, upwards or downwards. The pessimistic values were related to profitability: increase of $5 \%$ and $10 \%$, for cost items, and reduction of $5 \%$ and $10 \%$ for revenue items, resulting in a new Internal Rate of Return (IRR). This new result was compared with the average value, obtaining the variables with the most significant influence on the project's IRR, allowing the assessment of the viability of 'Niágara Rosada' grape production under adverse economic conditions.

According to Martins et al. (2016), this analysis identifies the variables that determine the success of the project but does not measure the risk associated with these variables. Considering that any economic feasibility study always has an inherent uncertainty factor, and the sensitivity analysis does not escape this rule, a risk analysis must be performed after completing the sensitivity analysis.

The Monte Carlo simulation (MCS) technique was used to assess the risk involved. The basic principle of this technique assumes that the relative frequency of occurrence of a particular phenomenon incidence tends to approximate the probability of occurrence of that same phenomenon when the experience is repeated several times (NORONHA, 1987).

According to Martins et al. (2016), MCS applies well to non-probabilistic problems and those with inherently probabilistic structure. Also noteworthy, the advantage over other numerical methods, which have $\mathrm{n}$-points of evaluation in an m-dimensional space to produce approximate solutions, the fact of obtaining the absolute error of their estimates decreasing to $n-1 / 2$, while all the others have an absolute error of estimate decreasing to $\mathrm{n}-1 / \mathrm{m}$ at most. This property gives $\mathrm{MCM}$ a considerable advantage in computational efficiency when $\mathrm{m}$, the size of the problem, increases (FISHMAN, 1995).

MCS, according to Pouliquen (1970), is convenient, as it does not involve sophisticated methodology and is easily applied through computer simulation; reliable because the winegrower will decide on the basis of a cumulative probability distribution and not on unique 
information, and does not require significant expenditure on extensive field research. Consequently, for the MCS, the sequence of the analysis procedure was as follows:

1. The most critical variables were considered random, and all others were deterministic, namely, those of constant value, already determined by the use of sensitivity analysis. In this case, the model assumed that the variables had a triangular distribution. This distribution applies well when there is a low degree of information about the variables because the distribution is defined by its average level or by fashion (Fs), extreme by a Minimum (Mn) and Maximum (Mx) levels, according to Pouliquen (1970).

2. A new cash flow was generated using a computer, represented by average, minimum, and maximum values. The random values for each chosen variable were considered relevant in the previous step, based on the identified probability distributions.

3. After selecting a value for each random variable (average, minimum and maximum value), the profitability indicators analyzed in the research were calculated. A profitability indicator, the NPV, was then calculated for this new cash flow.

4. These procedures were repeated (1000 times) to obtain the indicator's probability distribution (NPV). Finally, from the probability distribution of the NPV, the probability of a negative NPV was obtained.

Therefore, the accumulated probability distributions were obtained, indicating the degree of risk assumed by the winegrower in the regions. Examples of using this technique to address risk in agricultural activity can be found in studies by Machado Neto et al. (2018), Baitelle et al. (2018), Simões et al. (2015), Lyra et al. (2010), Ponciano et al. (2004) among others.

It is worth noting that both techniques are complementary in risk analysis. When sensitivity analysis is applied, the focus is on the variables and input parameters. In other words, the impact of variations in each variable or input parameter is verified separately, on a specific output variable. However, in Monte Carlo simulation, the highlight is for the output variable, seeking to generate, based on the probability distributions of the input variables and parameters and correlations between these variables and parameters, the accumulated probability function for the output variable, as Borges Júnior et al. (2008).

\section{Results and Discussions}

The study assessed the economic feasibility of cultivating 'Niágara Rosada' grapes in a trellised conduction system under a shade cloth screen with drip irrigation of 1 hectare, over a 20 -year cultivation horizon, in the North and Northwest Fluminense regions. The results of the study highlighted that viticulture presented positive NPV and IRR values, which enables activity in the regions, corroborating the data found by Reis and Reis (2016) and Cappelo et al. (2017) in the regions of the São Francisco Valley and the state of São Paulo, respectively.

As in the areas analyzed, the authors observed the production of the 'Niágara Rosada' grape in trellised production systems with irrigation, achieved more than one harvest during the year. Reis and Reis (2016) described the useful life of the vineyard equivalent to 20 years, as was also analyzed in the present work. Cappelo et al. (2017) considered only ten years for production, in addition to two years of implementation.

Figure 1 displays the results of the NPV, compared to the minimum attractiveness rates considered from 2 to $10 \%$ per year. NPV was positive $(>0)$, since the crop had a Net Present Value equivalent to R $\$ 83.075,09$, considering the minimum attractiveness rate of $6 \%$ per year.

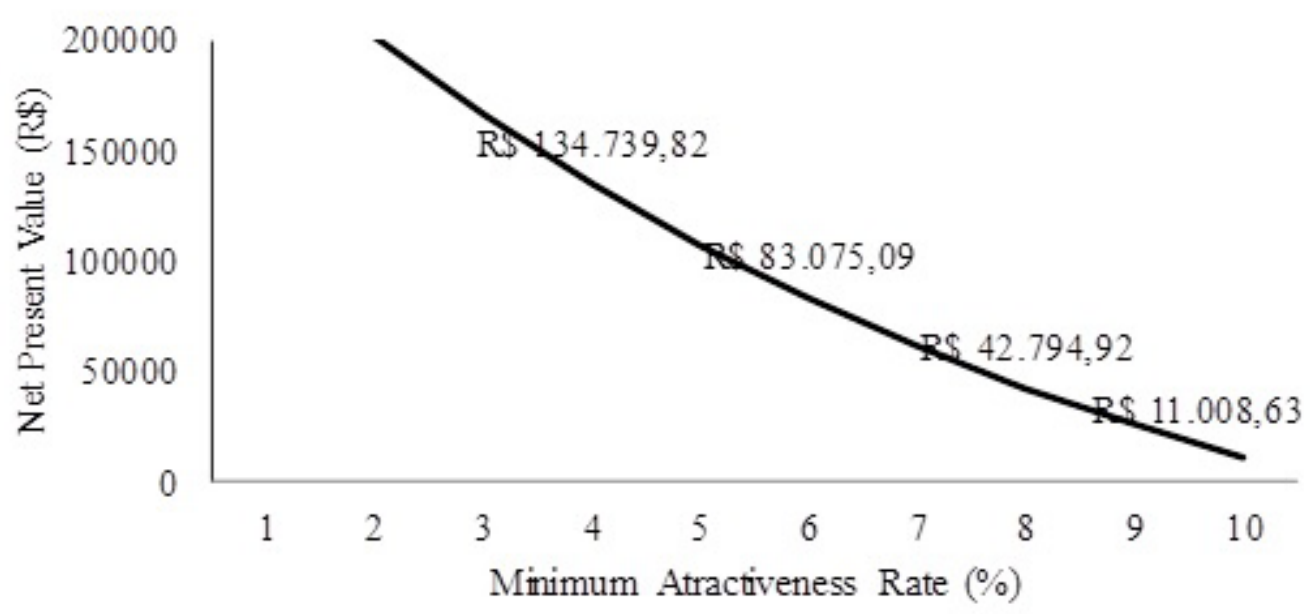

Figure 1. Net Present Value with planning horizons for 20 years of cultivation and Minimum Attractiveness Rate for the cultivation of grapes in the North and Northwest regions of the state of Rio de Janeiro. 
Grape production displayed $10.81 \%$ IRR per year, indicating the viability of cultivation since the activity presented this indicator higher than the considered minimum attractiveness rate. Gitman (2012) emphasizes that IRR is probably the most sophisticated technique for capital budgeting since it provides the annual rate of return of the production.

Table 1 presents the results of the sensitivity analysis, showing the effect on the IRR, considering an unfavorable variation of 5 to $10 \%$ in the prices of the inputs and grapes. From the results obtained, the items that most affected the financial results in viticulture in Rio de Janeiro were classified in order of importance.
The price of the grapes was the variable with the most significant impact on the internal rate of return of the production systems. A $5 \%$ reduction in the price of grapes would cause a $76.16 \%$ decrease in NPV (percentage) and would reduce the IRR by $3.58 \%$. With the $10 \%$ drop in the price received, the internal rate of return would decrease by $7.78 \%$, with a negative NPV equivalent to $(\mathrm{R} \$ 43.460,82)$.

Table 1. Decrease in NPV and IRR in the grape cultivation system due to an unfavorable variation of 5\% and $10 \%$ (raising cost items and reducing the price of the product) for the cultivar 'Niágara Rosada'

\begin{tabular}{ccccc}
\hline & TIR $(\%)$ & $(\%)^{*}$ & TIR (\%) & $(\%)^{*}$ \\
\hline Price of the product & $7.23 \%$ & $-3.58 \%$ & $3.03 \%$ & $-7.78 \%$ \\
Manpower & $9.64 \%$ & $-1.17 \%$ & $8.44 \%$ & $-2.37 \%$ \\
Packaging & $10.00 \%$ & $-0.81 \%$ & $9.15 \%$ & $-1.66 \%$ \\
Technical management & $10.40 \%$ & $-0.41 \%$ & $9.98 \%$ & $-0.83 \%$ \\
Fertilizers & $10.50 \%$ & $-0.31 \%$ & $10.18 \%$ & $-0.63 \%$ \\
System installation & $10.66 \%$ & $-0.15 \%$ & $10.51 \%$ & $-0.30 \%$ \\
Plant regulators & $10.61 \%$ & $-0.20 \%$ & $10.41 \%$ & $-0.40 \%$ \\
Pesticides & $10.70 \%$ & $-0.11 \%$ & $10.58 \%$ & $-0.23 \%$ \\
Irrigation system & $10.72 \%$ & $-0.09 \%$ & $10.63 \%$ & $-0.18 \%$ \\
Seedlings & $10.77 \%$ & $-0.04 \%$ & $10.72 \%$ & $-0.09 \%$ \\
Other inputs and services & $10.79 \%$ & $-0.02 \%$ & $10.77 \%$ & $-0.04 \%$ \\
Soil & $10.80 \%$ & $-0.01 \%$ & $10.78 \%$ & $-0.03 \%$ \\
Mechanized operations & $10.81 \%$ & $0.00 \%$ & $10.80 \%$ & $-0.01 \%$ \\
\hline
\end{tabular}

* Percentage points variation

The impact of the sale price of the product on the profitability of production systems has been observed in other agricultural activities, such as fruit and grain production, due to the uncertainties and seasonality inherent to agriculture (REIS; REIS, 2016; MARTINS et al., 2016; LYRA et al., 2010).

The results point out the labor as the second most important item, followed by the cost of packaging. Also, the data emphasize the impact on costs with technical management, fertilizers, and the installation of the system. The cost of mechanized operations had the least impact.

The economic importance of labor costs can be justified, in this case, by the characteristics unique to management operations in the vine culture, such as pruning and harvesting, which are activities where labor is crucial. These and other operations, when scheduled to distribute labor demand more evenly during periods of more significant crop needs, can minimize costs for the producer.
The economic importance of the packaging cost can also be justified by the peculiar characteristics of the commercialization of grape in trays. Trays add value to the product, ensure the best appearance at the purchase time, and avoid loss of the berries in the bunches.

Furthermore, it is important to highlight in the investment costs, the participation of the dark cloth screen on the system installations, which represent about $36.52 \%$ of the initial investment value (Figure 2). Screening has been crucial for the performance of the vines due to the edaphoclimatic conditions and pest control at fruiting. The costs of labor, irrigation equipment, and technical assistance represent the highest costs in the initial phase of implementing the crop. 


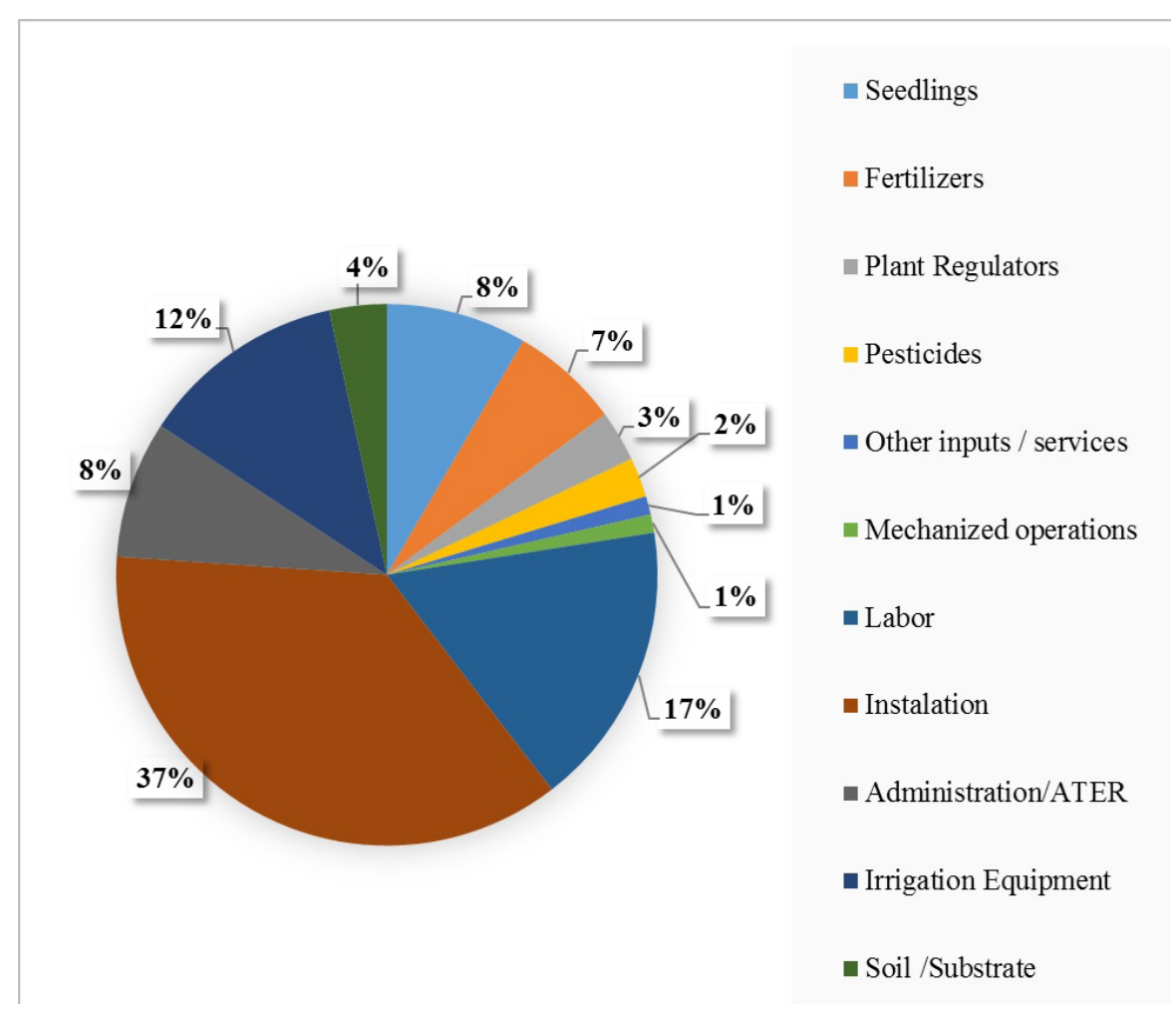

Figure 2. Percent composition of technical coefficients in the investment cost in 1 hectare of grape production.

Although economic analysis, based on indicators and sensitivity analysis, is essential, this analysis may be insufficient for safer decision-making. Thus, it is crucial to present the risk analysis to the producer to offer a quantitative estimate of the probability of adverse events and their consequences on the results of investment in grape. Figure 3 shows the cumulative probability distribution of the NPV obtained through Monte Carlo Simulation. It is worth noting that the pieces of information used are always projections for the future of the variables that make up the cash flow, and estimates are subject to error. Therefore, using the Monte Carlo Simulation, the probability that the winegrower will obtain a negative NPV was $33.32 \%$ over the 20 -year grape growing horizon, with an attractiveness rate of $6 \%$ per year.

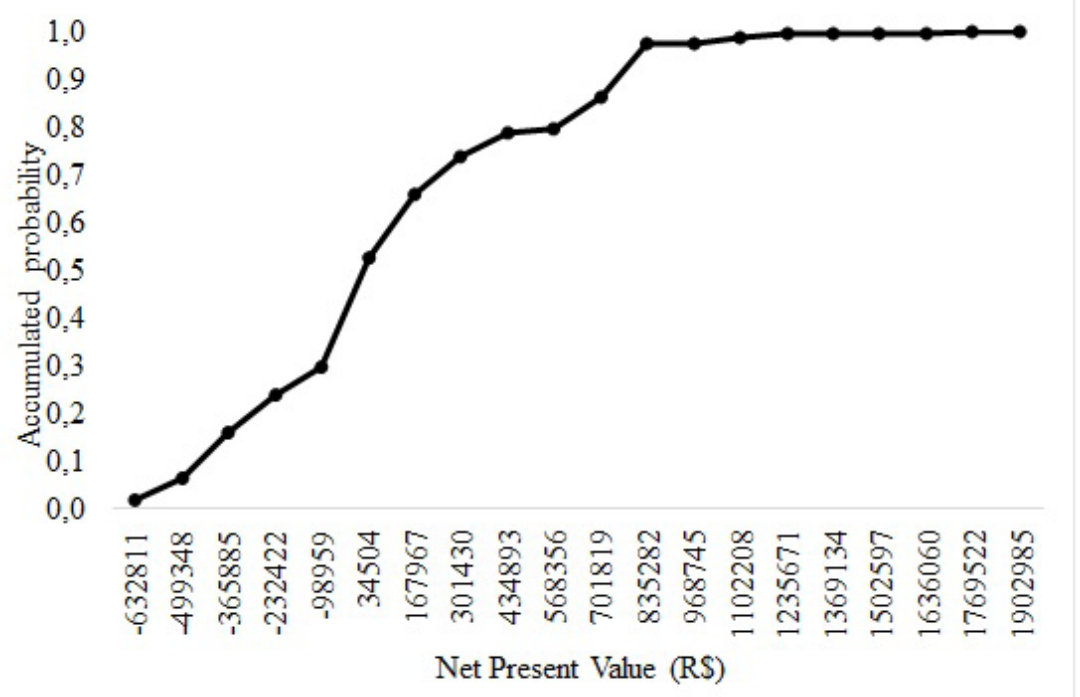

Figure 3. Accumulated probability distribution of the Net Present Value obtained through Monte Carlo simulation for the 'Niágara Rosada' grape culture in the North and Northwest Fluminense Regions. 
The price of the grape is the item whose variation has the most significant impact on the profitability of viticulture in Rio de Janeiro. Considering that the behavior of the market for agricultural products, such as grapes, presents high instability at the received prices, commercialization presents itself as one of the main problems for viticulture, as observed by other affordability analyzes in the field of fruit growing.

The various forms of commercialization and the optimization of the handling practiced on the vine can help mitigate the instability of the price paid to the producer and minimize the production costs. One of the particularities that viticulture presents in these regions is that, in some cases, producers sell most of their products inside the properties, reducing logistics costs and obtaining higher prices than those considered in the risk analysis. The higher prices are because the price of the small volume sale (retail) is higher than in large volume (wholesale).

Retail sale, besides providing a higher product's price, also creates an opportunity to develop agrotourism in the regions. The local agricultural support agencies must encourage this type of activity, such as in Jundiaí, in the São Paulo State.

\section{Conclusions}

The presented data highlight that viticulture is economically viable for the North and Northwest regions of Rio de Janeiro State. The sensitivity analysis revealed that the product's selling price is the variable with the most significant impact on profitability. The presented results also point out that, due to the frequency, which appears as an essential item in determining financial results, labor and the cost of packaging are factors of immense influence for the success of viticulture in Rio de Janeiro.

The probability of grape producers to obtain negative net present values was $33.32 \%$ over the horizon of grape cultivation in 20 years, with an attractiveness rate of $6 \%$ per year. In addition to economic risk, there are risks related to climate and phytosanitary issues. Although the adoption of technologies can avoid most of these events, it is necessary to know the specifics of the region so that the lack of tradition in the cultivation of grapes does not generate losses in the production process, raising the estimated risks.

The importance of the cost of labor is a direct reflection of the high demand for this factor during the cultivation of grapes with two harvests per year. Moreover, in addition to the economic aspects analyzed, viticulture can also generate great social benefits for the regions by creating jobs.
Future analyses should compare the Niágara Rosada with other cultivars that are being used. This action can influence the prices established and point out other aspects that may alter the cost spreadsheet and, consequently, other variables of impact on the profitability of viticulture in the regions.

\section{References}

BAITELLE, D.C.; JESUS FREITAS, S. de; VIEIRA, K.M.; MENEGHELLI, C.M.; VERDIN-FILHO, A.C.; BARONI, D.F., SOUZA, P.M. de. Feasibility and economic risk of programmed pruning cycle in arabic coffee. Journal of Experimental Agriculture International, Gurgaon, v.21, n.4, p.1-9, 2018.

BORGES JÚNIOR, J.C.F.; FERREIRA.P.A.; ANDRADE, C.L.T.; HEDDEN-DUNKHORST, B. Computational modeling for irrigated agriculture planning. Part II: Risk analysis. Engenharia Agricola, Jaboticabal, v.28, n.3, p.483-493, 2008.

BUARQUE, C. Avaliação econômica de projetos. 6.ed. Rio de Janeiro: Campus, 1991. 266 p.

CAPPELLO, F.P.; SPÓSITO, M.B.; OSAKI, M. Production costs and profitability of 'Niagara Rosada' table grape grown in different regions of São Paulo State. Revista Brasileira de Fruticultura, Jaboticabal, v.39, n.4, e.774, 2017.

FISHMAN, G.S. Monte Carlo: concepts, algorithms and applications. New York: Springer-Verlag, 1995. 698 p.

GITMAN, L.J. Princípios de administração financeira. 12.ed. São Paulo: Pearson Prentice Hall, 775p. 2012.

HESPANHOL-VIANA, L. Fenologia e quebra de dormência da videira 'Niagara Rosada' cultivada na região Norte Fluminense e diferentes épocas de poda. 2009. 74 f. Tese (Doutorado em Produção Vegetal) - Universidade Estadual do Norte Fluminense Darcy Ribeiro, Campos dos Goytacazes, 2009.

KREUZ, C.L.; SOUZA, A.; SCHUCK, Ê.; PETRI, J.L. Avaliação econômica de alternativas de investimentos no agronegócio da uva no meio oeste catarinense. Revista Brasileira de Fruticultura, Jaboticabal, v.27, n.2, p.230237, 2005. 
LYRA, G.B.; PONCIANO, N.J.; DE SOUZA, P.M.; DE SOUSA, E.F.; LYRA, G.B.Viabilidade econômica e risco do cultivo de mamão em função da lâmina de irrigação e doses de sulfato de amônio. Acta Scientiarum Agronomy, Maringá, v.32, n.3, p.547-554, 2010.

MACHADO NETO, A.DA SILVA, PONCIANO, N.J.; SOUZA, P.M.D.; GRAVINA, G.D.A.; DAHER, R.F. Costs, viability and risks of organic tomato production in a protected environment. Revista Ciência Agronômica, Fortaleza, v.49, n.4, p.584-591, 2018.

MARTINS, E.D.A.; CAMPOS, R.T.; CAMPOS, K.C.; ALMEIDA, C.D.S. Rentabilidade da produção de acerola orgânica sob condição determinística e de risco: estudo do distrito de irrigação tabuleiro litorâneo do Piauí. Revista de Economia e Sociologia Rural, Brasília, DF, v.54, n.1, p.9-28, 2016.

MARTINS, W.A; SANTOS, SC; SMILJANIC, K.B.A. Exigência térmica e produção da videira 'Niágara Rosada' em diferentes épocas de poda no Cerrado do Brasil. Revista de Ciências Agrárias, Lisboa, v.37, p.171-178, 2014.

NORONHA, J.F. Projetos agropecuários: administração financeira, orçamento e viabilidade econômica. 2.ed. São Paulo: Atlas, 1987. 269p.

PAREJA, I.V. Decisiones de inversión para la valoración financiera de proyectos y empresas. 6.ed. Buenos Aires: Fondo Editorial Consejo, 2009. 692 p.
PERMANHANI, M; VASCONCELLOS, M.A.S; SOUZA, R.T; MARTELLETO, L.A.P. Estimativa de área foliar da videira 'Niagara Rosada' conduzida em sistema de latada, região norte fluminense. Revista Brasileira de Fruticultura, Jaboticabal, v.36, n.4, p.1034-1040, 2014.

POMMER, C.V; MENDES, L.S; HESPANHOL-VIANA, L, BRESSAN-SMITH, R. Potencial climático para a produção de uvas em Campos dos Goytacazes, Região Norte Fluminense. Revista Brasileira de Fruticultura. Jaboticabal, v.31, n.4, p.1076-1083, 2009.

PONCIANO, N.J.; SOUZA, P.M.D.; MATA, H.T.D.C.; VIEIRA, J.R.; MORGADO, I.F. Análise de viabilidade econômica e de risco da fruticultura na região norte Fluminense. Revista de Economia e Sociologia Rural, Brasília, DF, v.42, n.4, p.615-635, 2004.

POULIQUEN, L.Y. Risk analysis in project appraisal. Baltimore: Johns Hopkins University, 1970.

REIS, L.P.; REIS, P.C.M. Viabilidade econômica do cultivo de uva irrigada no município de Petrolina, PE. Enciclopédia Biosfera, Jandaia, v.13, n.24, p.1089, 2016. SIMÕES, D.; CABRAL, A.C.; OLIVEIRA, P.A. Citriculture economic and financial evaluation under conditions of uncertainty. Revista Brasileira de Fruticultura, Jaboticabal, v.37, n.4, p.859-869, 2015.

TECCHIO, M.A.; DA SILVA, M.J.R.; CALLILI, D.; HERNANDES, J.L.; MOURA, M.F. Yield of white and red grapes, in terms of quality, from hybrids and Vitis labrusca grafted on different rootstocks. Scientia Horticulturae, New York, v.259, n.108846, 2020.

TECCHIO, M.A.; BETTIOL NETO, J.E.; BARBOSA, W.; TUCCI, M.L.S. Evolution and perspective of the temperate fruit crops in São Paulo state, Brazil. Revista Brasileira de Fruticultura, Jaboticabal, v.33, n.esp, p.150-157, 2011. 